give the observed values of $p / p_{i}$ for heptane-ethyl iodide mixtures at $50^{\circ}$ are given below (data by Smyth and Engel ${ }^{2}$ and Smyth and Stoops ${ }^{3}$ ):

\begin{tabular}{|c|c|c|c|c|}
\hline $\begin{array}{c}\text { Mol. } \\
\text { Fraction } \\
\mathrm{C}_{2} \mathrm{H}_{5} \mathrm{I} .\end{array}$ & $\begin{array}{c}\text { Observed } \\
\text { Partial } \\
\text { Vapour } \\
\text { Pressure } \\
\mathrm{C}_{2} \mathrm{H}_{6} \mathrm{I}(\mathrm{mm} .) .\end{array}$ & $\begin{array}{c}\text { Ideal Partial } \\
\text { Vapour } \\
\text { Pressure } \\
\mathrm{C}_{2} \mathrm{H}_{5} \mathrm{I} \text { (mm.). }\end{array}$ & $\frac{1}{D_{i}}-\frac{1}{D}$ & $\begin{array}{c}a \\
\text { (Angstrom } \\
\text { Units). }\end{array}$ \\
\hline $0 \cdot 1$ & $57 \cdot 3$ & $58 \cdot 8$ & 0.0574 & $1 \cdot 06$ \\
\hline $0 \cdot 2$ & 107.5 & 118.5 & $0 \cdot 1089$ & 1.28 \\
\hline 0.3 & $151 \cdot 7$ & 178.5 & 0.1557 & $\mathrm{I} \cdot 4 \mathrm{l}$ \\
\hline 0.4 & $188 \cdot 3$ & $238 \cdot 3$ & 0.1982 & 1.50 \\
\hline 0.5 & 218.0 & 297.8 & $0 \cdot 2384$ & 1.56 \\
\hline $0 \cdot 6$ & $243 \cdot 8$ & 357.5 & $0 \cdot 2749$ & $1 \cdot 61$ \\
\hline 0.7 & $268 \cdot 0$ & $417 \cdot 5$ & 0.3080 & $1 \cdot 65$ \\
\hline 0.8 & $292 \cdot 8$ & 477.5 & 0.3379 & 1.68 \\
\hline 0.9 & $321 \cdot 0$ & $537 \cdot 5$ & 0.3643 & 1.72 \\
\hline $1 \cdot 0$ & $354 \cdot 5$ & 598.0 & 0.3866 & $1 \cdot 75$ \\
\hline
\end{tabular}

These results are promising, and experimental work is now in progress with the object of testing this point of view further.

Chemistry Department,

University of Aberdeen, Aug. 7.

\footnotetext{
1 Martin, Phil. Mag., 8, 550; 1929: 9, 422; 1930.

2 Smyth and Engel; J. Amer. Chem. Soc., 51, 2646; 1929.

3 Smyth and Stoops, ibid., 51, $3312 ; 1929$.
}

\section{Atomic Hydrogen Occluded in Iron Nitride.}

Aтоміс hydrogen in iron has so far been known to be occluded when iron is quenched from a high temperature in water or when iron is electrolytically deposited. I have observed the exıstence of atomic hydrogen in iron nitride prepared by heating iron in the current of ammonia gas. I confirmed it by measuring the single potential of the iron nitride in normal ferrous sulphate solution. The time voltage curve of the iron nitride showed a minimum due to atomic hydrogen at the beginning, similar to that which appeared in the curve of iron quenched and loaded with atomic hydrogen, obtained by T. W. Richards. ${ }^{1}$

I also confirmed the existence of atomic hydrogen by immersing the iron nitride in a solution of potassium ferricyanide and observing the formation of Prussian blue on adding the ferric chloride solution. This reduction, $\mathrm{K}_{3} \mathrm{Fe}(\mathrm{CN})_{6}$ + atomic hydrogen $\rightarrow \mathrm{K}_{4} \mathrm{Fe}(\mathrm{CN})_{6}$, also takes place with the iron quenched in water, and thus loaded with atomic hydrogen, but never with ordinary iron.

Mitsubishi Research Laboratory, Tokyo, Japan.

${ }^{1}$ Zoit. physikal. Chem., 58, 310; 1907.

\section{Audibility of the Aurora Polaris.}

IT cannot be doubted that many persons have heard a distinct sound when watching a brilliant display of aurora. Naturally they have connected the two phenomena and have assumed that the sound was emitted by the aurora. Communications regarding the auroral sound appear now and then, and recently $\mathrm{Mr}$. J. H. Johnsen has collected a great number of reports on the auroral sound in his pamphlet, "Concerning the Aurora Borealis ", which has been reviewed in NATURE by Prof. S. Chapman. ${ }^{1}$ Examining these reports, one finds that the auroral sound, with few exceptions, is described as a weak but distinct swishing or hissing sound which is heard during auroral displays on calm nights and at low air temperatures. I wish to emphasise the fact that the air temperature, in the cases in which it is stated, ranges between $-35^{\circ} \mathrm{F}$. and $-50^{\circ} \mathrm{F}$

Very few investigators of the aurora admit that the sounds which have been heard can be ascribed to the aurora, but a satisfactory explanation of the observations is not yet commonly known, in spite of the fact that such an explanation has been given by Roald Amundsen in his book "The South Pole". Amundsen says (in translation from the original Norwegian edition, p. 417) : "The swishing aurora does not exist. What one hears is one's own breath which freezes in the cold air".

The 'swishing breath' is a phenomenon which is well known to many arctic travellers and to natives, but it has not often been mentioned in the scientific literature. J. v. Hann ${ }^{2}$ quotes observations of the 'swishing breath' from Siberia, and A. Wegener ${ }^{3}$ has discussed the phenomenon, which he has observed in Greenland at temperatures below $-44^{\circ} \mathrm{F}$.

From my own experience, I can confirm that when the air temperature is below $-40^{\circ} \mathrm{F}$. and calm prevails, one hears a swishing or hissing sound when exhaling, possibly because the water vapour of the breath immediately condenses to ice crystals which collide when falling to the ground. The sound of the freezing breath is very distinct but weak, and is, therefore, heard only when the observer is standing still and listening intently. The phenomenon is very puzzling to an unexperienced observer, and if several persons are standing together it is impossible to become aware of the real cause of the sound. In that case the sound naturally is connected with any conspicuous phenomenon which occurs simultaneously, for example, an aurora. In the arctic the sky is generally clear when the temperature is low and the air is calm, and in the zone of maximum auroral frequency an auroral display is seen on nearly every clear night. An observer standing still and watching a brilliant display then hears a weak swishing sound, rising rhythmically, and naturally he assumes that this sound is emitted by the aurora.

I do not claim that the sound which has been ascribed to the aurora was always the sound of the freezing breath, but I am convinced that such has been the case in by far the greater number of instances in which persons report having 'heard the aurora'. It would be of interest to study more closely the conditions at which the sound of the freezing breath is heard, and also to direct the attention of auroral observers to the phenomenon in order that in the future the swishing breath is not interpreted as 'auroral sounds'.

Chr. Michelsens Inst., Bergen, H. U. SverdruP. July 27.

1 " The Audibility and Lowermost Altitude of the Aurora Polaris." NATURE, March 7, 1931, p. 341.

2 Handb. d. Klimatologie, Bd. 3, 3. Aufl., Stuttgart, 1911, p. 643.

${ }_{8}$ Handb. d. Klimatologie, Bd. 3, 3. Aufl., Stuttgart, 1911, p. 643. hagen, 1930 , p. 496 .

\section{The Harvard Museum Expedition to Australia.}

THE announcement made by Science Service, and commented upon in NaTURE of July 11, evidently gives a misleading idea of the objects sought by the Harvard Museum Expedition to Australia. It is not primarily an expedition to secure specimens for a museum, but for the study of the animals of the region when alive. Such work necessarily entails the killing of a limited number of forms, so as the better to understand their habits, feeding, movement, reproduction, and so on. But the "bag ' thus sought is trivial and not to be compared to the long series valued by philatelists and many former collectors of animals and plants. The idea of vastly long series is dead so far as 